\title{
Starozavezne predpodobe Marije in podobe Judov $v$ slovenskih nabožnih pesmaricah v različnih obdobjih Katoliške cerkve ${ }^{1}$
}

\author{
Old Testament Preimages of Mary and \\ Images of Jews in Slovene Religious Hymnals \\ in Different Periods of the Catholic Church
}

Izvleček: V prispevku odkrivamo, katere dogodke in osebe Stare zaveze nam kot Marijine predpodobe posredujejo slovenske nabožne pesmarice $\mathrm{v}$ različnih obdobjih Katoliške cerkve. Njene znane predpodobe so še posebej Davidov in slonokoščeni stolp, duhovna posoda, skrinja miru, lilija, roža brez trnja, studenec milosti, negativno konotacijo pa imajo predvsem primerjave s starozaveznim likom Eve, še posebej v obdobju baroka. V baročnih eshatoloških pesmih, ki so pri vernikih vzbujale strah in obsojanje, je večkrat viden prezir do Judov (tudi muslimanov); te pesmi so že v obdobju razsvetljenstva začeli izločati iz liturgične rabe v Cerkvi. Tematiko kolektivne krivde Judov za Kristusovo trpljenje in smrt najbolj nazorno prikazujejo pasijonske pesmi.

Ključne besede: Marijine pesmi, eshatološke pesmi, pasijonske pesmi, predpodoba, slovensko slovstvo, Stara zaveza, judovstvo

\begin{abstract}
The article discovers which events and persons of the Old testament are transmitted to us as Mary's pre-images by Slovene religious hymnals in different periods of the Catholic Church. Her well-known pre-images are the Tower of David and the Ivory Tower, a spiritual vessel, a chest of peace, a lily, a rose without thorns, a fountain of grace, while comparisons with the Old Testament figure of Eve express a negative connotation, especially in the Baroque period. In Baroque eschatological songs, which aroused fear and condemnation, contempt for Jews (including Muslims) is often seen; these songs began phasing out of the liturgical use in the Church in the Age of Enlightenment. The theme of the collective guilt of the Jews for Christ's suffering and death is most vividly illustrated by the Passion Songs.
\end{abstract}

Key Words: Songs of Mary, eschatological songs, passion songs, pre-image, Slovenian literature, Old Testament, Judaism

1 Prispevek je nastal v okviru raziskovalnega programa Literarnozgodovinske, literarnoteoretične in metodološke raziskave (P6-0024), ki ga financira Javna agencija za raziskovalno dejavnost Republike Slovenije. 


\section{Uvod}

Podoba Marije v slovenski nabožni pesmi je tesno povezana s podobo, ki so jo oblikovali pisci svetopisemskih besedil, cerkveni očetje in učitelji $\mathrm{v}$ antiki ter srednjem veku. Temu se pridružuje tudi ljudska ustvarjalnost, ki je v literarna besedila vnašala številne apokrifne elemente, neskladne z uradnim učenjem Cerkve. V evangelijih je Marija predstavljena kot Jezusova mati, trpeča Božja mati pod križem, Devica, vernica in Kristusova učenka ter zvesta žena. V novozaveznih besedilih pa so že nakazane preroške in tipološke povezave s Staro zavezo, od katerih so številne prepoznane kot Marijine predpodobe. Še posebej v dobi patristike so Marijo povezovali s starozaveznimi ženskimi liki, kot so Eva, matriarhinje Sara, Rebeka, Rahela, Lea, Ana, prerokinje, zmagovalke in kraljice Mirjam, Debora, Jaela, Judita, Estera ter ženske z obrobja Tamara, Rahaba, Ruta in Batšeba. Cerkveni očetje so njeno deviškost in materinstvo povezovali s številnimi metaforami, npr. z gorečim grmom, Aronovo palico, lilijo, Gideonovo runo, tempeljskimi in nebeškimi vrati, rajskim vrtom, neobdelano skalo ter skrinjo zaveze. Marijo so prepoznavali kot nevesto, zaročenko in Sionsko hčer, predstavljala je poosebljeno Modrost, v navezavi s Salomonom pa je že kmalu postala sedež modrosti. ${ }^{2}$ Namen prispevka je predvsem poiskati omenjene in nekatere druge starozavezne elemente v slovenskih nabožnih pesmaricah ter opazovati morebitno spreminjanje njihovega pomena v različnih obdobjih Cerkve.

Poleg številnih starozaveznih elementov, ki se navezujejo na Marijo, pa so v slovenski nabožni pesmi opazni tudi nekateri drugi, ki se neposredno oz. posredno navezujejo na Jude iz obdobja drugega templja oz. Jezusove sodobnike, redkeje na srednjeveške, njihova podoba pa je praviloma negativna. To velja tudi za nekatere svetopisemske osebe moškega spola, kot so Kajn, Adam in Juda Iškarijot. Sovražnosti in predsodki proti Judom so v Evropi vodili do preganjanj v poznem 15. stoletju. Med judovske arhetipe so spadali zlasti domnevni obredni umori krščanskih otrok, onečaščenje hostije, izvajanje magičnih obredov s krščansko krvjo, zastrupljanje vodnjakov, oderuštvo in denarne goljufije (Valenčič 1992, 16.24.26; Bronner

2 Podrobnejšo obravnavo podobe Marije v Novi in Stari zavezi, zgodnjem krščanstvu in slovenskih legendarnih ter nabožnih ljudskih pesmih skupaj z navedbo najnovejših referenc s tega področja glej v Brozovič 2019, 9-150. 
2007, 383; Matteoni 2008, 182; Livak 2010; Avsenik Nabergoj 2016, 179-189; Mlakar 2019, 179-186). Šele evropsko razsvetljenstvo 18. stoletja je rodilo številne mislece, ki so zagovarjali človekove pravice, civilne svoboščine in versko strpnost ter kritizirali absolutistično upravljanje države in Cerkve (npr. Voltaire). Tolerančni patent Jožefa II. iz leta $1781^{3}$ je omogočil enake državljanske pravice pravoslavnim Grkom, protestantom in Judom v habsburški monarhiji. ${ }^{4}$ Vendar so Judje dobili pravico do opravljanja bogoslužja le tam, kjer so bili naseljeni: v Trstu, Gorici in Prekmurju, ne pa tudi v mestih, kot je Maribor, od koder so bili izgnani že v 15. stoletju. Ambrožič (2011, 16) poudarja, da je bilo ljudstvo sicer naklonjeno verski toleranci, za rimsko kurijo pa je ta pomenila oškodovanje pravic Cerkve in zmago indiferentizma. Naslednji cesarski patent (1849) je Judom zagotovil svobodo vere, vesti in bogoslužja, ustava iz leta 1867 pa je odpravila še omejitve glede naseljevanja, preseljevanja in priseljevanja, posesti, nepremičnin in opravljanja pridobitne dejavnosti. Protijudovstvo, ki je bilo predvsem verske narave in prisotno že v grško-rimskem svetu, je v 19. stoletju nadomestil politično usmerjeni antisemitizem. Od leta 1941 so se slovenski Judje, ki so bili nasploh maloštevilni, ${ }^{5}$ začeli izseljevati v ZDA, nekaj jih je bilo interniranih v taborišča (Toš 2012, 231-232). Cerkev je uradno izjavo o verski svobodi podala šele na II. vatikanskem koncilu (Dignitatis Humanae, 1965), ko je bila potrjena tudi izjava o razmerju Cerkve do nekrščanskih verstev (Nostra Aetate), ki obsoja antisemitizem. V prispevku raziskujem, v katerih nabožnih pesniških žanrih so prisotne omembe Judov in kakšen odnos do njih izražajo tvorci pesmi. Ti so bili lahko predstavniki Katoliške cerkve (nižja duhovščina, meništvo), v 18. stoletju pa tudi vedno bolj številni laiki (učitelji, organisti, cerkovniki), ki so s pesmijo želeli ugajati ljudstvu, ki jih je financiralo. Zato so v slovensko nabožno pesem velikokrat vdirali elementi, ki se niso skladali z uradnim učenjem Cerkve, so pa izražali vero slovensko govorečega ljudstva v določeni dobi. Na negativno podobo Judov v slovenski nabožni ljudski pesmi je opozorila že Zmaga Kumer (1997), ki je pregledala pesmi v več zvezkih Štrekljevih Slovenskih narodnih pesmi,

3 Z izdajo patenta je bilo dovoljeno privatno izvrševanje obredov, grajenje molilnic na vsakih 100 družin, nastavljanje lastnih duhovnikov, ustanavljanje šol in zaposlovanje učiteljev, nadzor nad njimi pa je izvajala država (Rajšp 2011, 76)

4 Že papež Benedikt XIV. (1740-58) je Mariji Tereziji v njenih deželah dovolil tolerirati protestante (Ambrožič 2011, 13)

5 Leta 1836 je bilo v Prekmurju 211 Judov (in 35.186 katoličanov), leta 1880 je njihovo število sicer naraslo na 1082, vendar se je do leta 1941 to le še zmanjševalo in padlo na 366 (Toš 2012, 32-34). 
vendar je figuro Judov iz Jezusovega časa zasledila le v legendarnih, srednjeveške Jude pa v dveh pripovednih pesmih. Pri slovenskih literarnih zgodovinarjih na negativno podobo Judov v slovenski nabožni pesmi, sploh v baročni rokopisni produkciji, doslej še ni bilo opozorjeno.

Za potrebe prispevka sem pregledala celotno slovensko nabožno pesniško tradicijo 17., 18. in 19. stoletja, ki jo je večidel popisal in ovrednotil Marijan Smolik (2011), zadnja leta pa je bila dopolnjena in javnosti posredovana v spletni obliki v Registru slovenskih rokopisov 17. in 18. stoletja (NRSS). K preureditvi slovenske cerkvene glasbe pa tudi repertoarja pesniških besedil je pripomoglo cecilijansko gibanje v drugi polovici 19. stoletja, še posebej z ustanovitvijo orglarske šole leta 1877, s tem pa $z$ večjo izobraženostjo organistov (Škulj 2003, 30), in z izdajo nove cerkvene pesmarice leta 1883 pod uredništvom skladatelja Antona Foersterja; leto kasneje je tudi na Štajerskem izšel Cerkveni orglavec na deželi Gregorja in Karla Tribnika, ki je želel poenotiti in izboljšati izvajanje cerkvene glasbe v Cerkvi. Za primerjavo teh pesmaric s sodobnimi tiski 20. stoletja je najbolj relevantna in tudi najobširnejša pesmarica Slavimo Gospoda, v obravnavo pa sem sprejela še slovenske prevode himn izpod peresa Franca Ksaverja Lukmana. ${ }^{6}$

\section{Marija kot nova Eva in druge starozavezne predpodobe}

Krščansko razumevanje starozaveznih besedil je velikokrat kristološko; to pomeni, da so preučevalci Svetega pisma določene dogodke in osebe iz Stare zaveze razumevali kot pripravo na prihod Mesije. Ta starozavezna prerokba se je uresničila z odrešilnim delovanjem Jezusa Kristusa, opisanim v evangelijih. Predpodobe posredno nakazujejo to, kar bo sledilo v prihodnosti. Tudi za Marijo so cerkveni očetje uvedli številne predpodobe, kot so: prva med sionskimi hčerami, Estera, Judita, Eva, polna luna, živi studenec, lilija med trnjem, Noetova barka, vrtnica brez trnja, sedež modrosti, ogledalo pravice, duhovna posoda itd.

6 O prenovi cerkvene pesmi po II. vatikanskem koncilu skladatelja Zafošnika (glej Oblonšek 2018). 
Prosilni nagovori (litanije) in klici (kyrie eleison) so prvi znanilci rabe slovenskega jezika v srednjeveški Cerkvi (slavilni klic k Sveti trojici, litanijski prošnji klic). Lavretanske litanije Matere božje so bile potrjene leta 1587, v slovenskem jeziku so bile prvič natisnjene v Stržinarjevi pesmarici iz leta 1729, vendar so se v slovenščini izgovarjale gotovo že v 17. stoletju, o čemer nam pričuje škof Hren leta 1616 (Smolik 2011, 1307). V času papeža Leona XIII. so se dodajale molitvi rožnega venca. V slovensko nabožno pesem so vnesle številne metafore za Marijo, ki so bile sicer znane že $\mathrm{v}$ antiki in srednjem veku. Jezuiti so z misijonskim delovanjem $\mathrm{v}$ naših deželah kmalu začeli širiti mnoge nove pesmi. Med njimi je omembe vredna v 18. stoletju objavljena Marijina litanijska pesem (Smolik 2011, 351), ki se je med ljudstvom razširila v Parhamerjevem katekizmu, prevedenem tudi v slovenski jezik (glej ljubljansko izdajo 1762 in graško izdajo 1764 ter Foglarjev rokopis 1757-1762). Izvajanje pesmi je bilo razdeljeno med ljudstvo in zbor, s prepevanjem pa so verniki podobno kot z izgovarjanjem lavretanskih litanij ponotranjali Marijine atribute. V prvi kitici litanijske pesmi za usmiljenje prosijo Sveto trojico, v naslednjih kiticah pa izvemo vse verske resnice o Mariji (Božja mati, devica, brezmadežna), ki se prepletajo s prošnjim klicem. V častilnem delu je Marija poimenovana z različnimi metaforami, npr. ogledalo (podoba) pravice, stol (sedež) modrosti, posoda pobožnosti, skrivna roža svetosti brez trnja, skrinja Božjega mira, duhovna posoda, hiša zlata. Še posebej je znana primera iz Visoke pesmi, v kateri zaročenec vrat svoje izvoljenke primerja z Davidovim stolpom.

7

Smilena si ti divica, nam vsem verna pomočnica, špegel ti pravice si ino stol te modrosti. \&c.

8

Ti si sama zrok Marija, celega sveta veselja, o dühovna posodva, posodva poštüvana. \&c. 
Posodva vse pobožnosti,

skrivna roža te svetosti,

na keri nega trnja

ne greha nikakšega. \&c.

10

Zoveš se türen Davidov, türen s kosti elefantov, hiša si ti prelepa, puna čistega zlata. \&c.

\section{1}

Ti skrinja Božjega mira, skoz te se nebo odpira, lepa zgodna denica, bodi nam pomočnica. \&c. (Obchinzka knisicza zpitavanya 1764)

V Prvi knjigi kraljev najdemo mogočen opis Salomonovega sedeža (glej $1 \mathrm{Kr}$ 10,18-20), ki je postal predpodoba za Marijo že v srednjem veku (sveti Avguštin in Bernard). V starozavezni knjigi Pregovori je modrost predstavljena kot božanska oseba, torej Modrost z veliko začetnico (glej Prg 8,22-31). Teologi jo interpretirajo kot Logos, učlovečeno Besedo, pri čemer je Marija kot izbranka in »bogorodica« imela veliko vlogo. Naziv sedež modrosti (sedes sapientiae) torej predstavlja Marijo kot personificirano Modrost, sedečo na Salomonovem prestolu. V umetnosti je sicer velikokrat uprizorjena kot sedeča na prestolu z otrokom v naročju (Lechner 1994, 113-118). Treba je še omeniti, da je sama feminizacija modrosti (in s tem Boga) za teologe večkrat problematična (Healy 1985, 33). Predpodoba sedeža je prešla v mnoge slovenske baročne pesmi, med katerimi je omembe vredna Paglovčeva častilna Veseli se Marija Divica izvolena (ok. 1733), ki je bila v slovenskem jeziku zapisana že v 17. stoletju (glej Ševeljski rokopis). Kitice v tej pesmi so sestavljene iz častilnega in prosilnega dela; v 6. kitici je Marija imenovana lepi sedež v nebesih (v 1. kitici je omenjeno njeno vnebovzetje), nato je poudarjena njena materinska vloga Božjemu Sinu, ki se je utelesil in prebival na zemlji. Sesanje mleka je tipični starozavezni motiv, ki se nanaša na prestolnico Jeruzalem (prim. Iz 60,16). Sledi poziv vernika, naj ga Božja Mati polije z medenim mlekom, ki v starozaveznem kontekstu 
predstavlja blagostanje (prim. 2 Mz 3,8), v novozaveznem pa osnovno človekovo potrebo, ki pa se razlikuje od "močne hrane», ki pomeni duhovno hrano (1 Kor 3,2; Heb 5,12.13). ${ }^{7}$ Omemba kaplje krvi v kitici se gotovo nanaša na Kristusovo trpljenje.

Ti si ta lepi sedež, ker v nebesih sidiš, Bug je tvoje prsi sesov, keder je na sveti biv, vlij vlij, Mati vlij čes me eno kaplo krivi mleka medeniga, čes me navredniga. O Marija. (Paglovčeva pesmarica, fol. 202v)

Cerkveni očetje so že v srednjem veku razvijali številne podobe za Marijino devištvo. Da je Marija cvet na Evini vejici, ki je njeno trnje ne poškoduje, je v 5. stoletju zapisal pesnik Sedelius (Gambero 1999, 284-285), v znani sekvenci pesnika Adama od Svetega Viktorja iz zgodnjega 12. stoletja Salve, mater Salvatoris je Marija poimenovana flos de spina, spina carens. Trnje v krščanski simboliki predstavlja greh in njegove posledice, zato Marija kot immaculata predstavlja rožo brez trnja, greha (rosa sine spinis), lavretanske litanije pa so uvedle še pojem rosa mystica, ki se povezuje s čudežem učlovečenja v deviški Mariji in njeno povezanostjo z večno Modrostjo (Schmidt 1993, 548). Motiv Marije kot rdeče rože (vrtnice) brez trnja, bele lilije in celo potonike je pri nas uvedel tuhinjski župnik Mihael Paglovec v pesmi z začetnim verzom »Marija lep cir teh nebes«. Motiv je razviden še v slovenskih pesmih 19. stoletja (glej Ogrin 2019, 121):

Bela si koker lilija

Brez trnja ardeča gartraža

Precvetaš koker batonika

Marija roža cartana. (Paglovčeva pesmarica, fol. 204r)

Marija je v nabožnih pesmih 18. stoletja pogosto imenovana Noetova barka, skrinja zaveze, Davidov stolp, Jakobov (oz. živi) studenec (prim.

7 Več o metafori mleka v Svetem pismu glej v Jobes 2005, 134. 
Jn 4,6) in Salomonov tempelj, v pesmi trboveljskega organista Kadunca iz leta 1798 najdemo tudi primerjavo z ženskim starozaveznim likom Suzane, Jojakímove žene, ki so jo po krivem obtožili nečistovanja (glej DanD 3). Primerjava je povezana s Suzanino in Marijino deviškostjo, vendar je Marija v pesmi povzdignjena nad vse device (»Divica vsih Divic $)$. V teologiji cerkvenih očetov barka ponazarja Cerkev samo, v zvezi z Marijo pa materino naročje, v kateri se po Kristusu rodi novo življenje (Rahner 1964, 546). Barka v slovenski pesmi Antona Kadunca prestavlja varno pribežališče grešnikov. Jakobov studenec je omenjen v Janezovem evangeliju, ko je Jezus prispel v samarijansko mesto Sihár in neki Samarijanki ponudil živo vodo. V Paglovčevi pesmi je voda v tem studencu povezana s Kristusovo krvjo, ki odrešuje, kar je izvirna predelava iste kitice iz starejšega Ševeljskega oz. Semeniškega rokopisa. Cerkveni očetje so začeli povezovati Marijo s skrinjo zaveze po Efeškem koncilu (431). Gregorius Thaumaturgus jo imenuje skrinjo svetosti (prim. Ps 132,8), Janez Evbojski pa je zanjo uvedel poimenovanje arca foederis in jo tako povzdignil nad Noetovo barko in Mojzesovo skrinjo zaveze (Schildenberger in Scharbert 1988, 616). V Paglovčevi pesmi je Marija imenovana zlata skrinja (arka) Stare zaveze, ki je izpolnila pričakovanja starozaveznih očakov, patriarhov.

Ti si ta barka Noeta, kir se bo v njo zaparu, tist pred vodo na trapeta, ne bo utonov se vderu, o grejšnik, imaš nad sabo teh grejhov čez glavo, hitru se skrij nu se zapri $\mathrm{v}$ to barko h Mariji.

$[\ldots]$

Ti si Salamonov tempel, povn gnad nu svetusti, ti s en pravi eksempel narlepši čednosti, sveta na zemli v nebesih nu čedna od vsih 
Buh te je zbrav inu nam dal, de nas rešiš s težov.

O ti prečista Suzana, Divica vsih Divic, o kaj je klagvajna, prut tebi vnkaj z vic, te prosjo za usmilejne, deb ble skorej rešene, kaj je dušic, vsem jeh iz vic, tojeh bratov sestric. (Kadunčeva pesmarica, fol. 117v-188r)

Ti si ta zlata arka testamenta stariga, ti sveti patriarhi zdavnej na te čakali, skleni, skleni, Mati skleni, grešnike v nebesa peli, Mati izvolena, Milosti polhena. O Marija.

Ti si arka Noetova, močnu zaklenjena, vsi, kateri žalost nosijo, k tebi se pertožijo, teci, teci, grešnik teci v leto ar[k]o se ti zapri, notri zmiram sediš, hudiča se na bojiš. O Maria.

Ti si studenc Jakobov, lep, čist inu svetov, Sinu si nam rodila, zveličarja vsiga sveta, pij pij, grešnig pij studenc te milosti, ti grešnig vrednu pij pravo Jezusovo kri, o Marija. (Paglovčeva pesmarica, fol. 203r-203v) 
Marijo je Katoliška cerkev že zelo zgodaj začela povezovati z Evo (Justin Mučenec, Irenej in Tertulijan), podobno kot je Pavel v Pismu Rimljanom Adamov greh povezal s Kristusom. Eva je postala nekakšen antitip Marije, saj je že v novozaveznih epistolah pridobila negativno pojmovanje ( 2 Kor 11,2-3; 1 Tim 2,13-15) (Scharbert 1989, 418; Laato 2016). Cerkveni očetje (Epifan, Leon Veliki, Izidor Seviljski) so se pri ideji, da je Marija kači strla glavo, sklicevali na Efrema Sirskega: „Ker je kača prizadela Evo s svojimi kremplji, jo je Marijina noga poškodovala.« (Gambero 1999, 117) Ta dualizem se je izrazito stopnjeval zlasti v srednjem veku. Iz tega časa je še posebej znana Marijina himna pesnika Fortunata z naslovom Quem terra, pontus, sidera, vključena v rimski brevir (glej Lukman 1958, 100-101). Ta misel je prodrla tudi v slovensko katoliško pesem v 17. in 18. stoletju. ${ }^{8}$ Pesniki so poudarjali predvsem njeno posredništvo pri Bogu (Smolik 2011, 1360), kar je razvidno iz Ševeljskega rokopisa (1612-1672), ki poudarja, da je Eva s svojo prošnjo, željo, pogubila človeštvo, medtem ko je Marija s svojo pohlevnostjo uničila hudiča in vsem ljudem odprla nebesa:



Tudi baročna adventna Pesem od Adama in Eve Mariji pripisuje vlogo soodrešiteljice človeštva, saj je premagala kačo, ki je Adama in Evo zapeljala v greh. Antiteza Marija - Eva naj bi v renesansi izgubila prejšnji pomen, Marijo pa so vedno bolj začeli navezovati na oba prva starša (Sebald 1989, 420), kar je razvidno iz rokopisne Foglarjeve pesmarice iz leta 1757:

8 V protestantskih pesmaricah 16. stoletja je poudarjeno zgolj, da smo po Adamu vsi grešniki (Smolik 2011, 1085.1202) 
O Adan nu Ejva

Grešnika prva

Vesela postanta

Marija kaču premagala (Foglarjeva pesmarica, fol. 29r)

Ta dogodek so opevale tudi slovenske pesmi zgodnjega razsvetljenstva, npr. Redeskinijeva pesem o Marijinem brezmadežnem spočetju, saj je paralela Eva - Marija imela posebno vlogo pri potrditvi Marijine dogme o brezmadežnem spočetju leta 1854 (Söll 1989, 421). V slovenski pesmi iz leta 1775 najdemo polno predpodob za Marijo in tudi primerjav njene zasluŽnosti s starozaveznimi ženskimi liki, kot sta Estera in Judit (Smolik 2011, 1516); pesnik poziva t. i. sionske hčere, naj pridejo častit Devico Marijo, uporablja pa tudi druge svetopisemske predpodobe, kot so voda živega studenca, lilija med trnjem, živo drevo, Noetova barka, golobica. Pesem se je prepisovala še v prvi polovici 19. stoletja (Rokopis iz Zaklanca, 1828; Rokopisna pesmarica Sebastijana Gladesa, 1834). V pesmi je poudarjeno, da je Marija prosta izvirnega greha, saj je premagala kačo in tudi Holoferna, vrhovnega poveljnika oboroženih sil asirskega kralja Nebukadnezarja (glej Jdt 2):

Glasu hudičovmu mesta ni dala, ke pršla je božja gnada naprej, tok je pojrbanmu grehu vbejžala od svojga, od ptujga madeža frej.

Tok je kači srečnu glavu strla, toku je groznemu Judit Holofernu moč odvzela. (Redeskini 1775, 117)

Cecilijina pesmarica, ki je bila natisnjena kot del prenove cerkvene pesmi v drugi polovici 19. stoletja, je motiv kače kot Evinega atributa zamenjala celo s pošastjo:

V Božji lasti in oblasti

Bila si od vekomaj;

Glavo strla si pošasti,

Nam odprla sveti raj. (Cecilija 1902, 58) 
Kapucinski pater Hipolit nam je v začetku 18. stoletja ohranil lekcionarsko pesem Stella Caeli extirpavit, kjer izvemo, da je Marija (imenovana zvezda nebeška) z dojenjem Kristusa premagala smrtno kugo, ki jo je zasadila Eva (Ogrin 2019, 243). Adventna pesem Moja duša začni peti kranjskega organista Ambrožiča (1775), ki jo je prepisal trboveljski organist Kadunc (1798), pripoveduje, da se bodo z adventnim dogodkom znova odprla nebesa, ki so se zaprla zaradi Evinega greha. V umetnosti se ta podoba pojavi na vratih katedrale Hildesheimer Dom iz leta 1015, še bolj nazoren je prikaz v znanem Bernwardovem evangeliju (1015) (Sebald 1989, 419). Zato so se slovenski verniki Mariji priporočali ob smrtni uri. Pisec slovenske pesmi je Marijino lepoto primerjal tudi z Rahelino. V ikonografiji je ta pogosto prikazana kot izvoljena nevesta, Cerkev, v nasprotju s svojo sestro Leo, ki predstavlja sinagogo (Nitz 1993, 400):

O Marija lejpa Rahel,

o še lejpši tavženkrat,

nad tabo ni mogu angel

ta ner majši grejh spoznad,

o jest sim grejšnik na svejti,

ta narveči tu sposnam,

skorej bodem mogu umreti,

teb Marija se čez dam. (Anton Kadunc, fol. 116r)

Tudi srednjeveška himna Ave Maris Stella, v slovenščino prvič prevedena sredi 17. stoletja v Kalobškem rokopisu, razvija misel, da je Marija z dogodkom angelovega oznanjenja spremenila ime nepokorne Eve (iz Ave v Eva) (Ogrin 2019, 33). Negativno pojmovanje Evine vloge v odrešenjski zgodovini zasledimo še v razsvetljenskih pesmaricah (npr. Volkmer 1805). Bogoslužna pesmarica Slavimo gospoda $(1988,1998)$ je drugo kitico spremenila tako, da je Marijo poimenovala kot drugo Evo, spremembe v pesmi pa so se vršile že v predkoncilskem obdobju v okviru cecilijanskega gibanja (glej Cecilija 1901, 188; Lukman 1958, 101):

Selstvu si prijela

Iz vust Gabrijela,

Spremenila ime

Nepokorne Eve. (Kalobški rokopis 1973, 147) 
Ave - te pozdravlja

Gabrijel, nadangel,

Srečno drugo Evo,

Ki nam mir prinašaš. (Slavimo Gospoda 1998, 293)

\section{Negativne podobe Judov v slovenski nabožni pesmi}

Podoba Judov v slovenski nabožni pesmi je odraz predstave, ki jo je stoletja gojila Katoliška cerkev, ne pa tudi dejanske predstave slovenskega ljudstva, ki z Judi v tem času ni sobivalo (vsaj ne na Kranjskem, Štajerskem in Koroškem). Krščansko protijudovstvo temelji na prepričanju, da so Judje kolektivno odgovorni za Kristusovo smrt. Poleg grešnika Adama kot antitipa Jezusa in bratomorca Kajna kot antitipa Abela je v srednjem veku podobo judovskega izdajalca prevzel Kristusov učenec Juda Iškarijot (Gans in Leerssen 2007, 203). Duhovniki, ki so službovali v notranjeavstrijskih deželah v 18. stoletju, pa za Kristusovo smrt in trpljenje niso krivili samo Judov, temveč so poudarjali, da tudi kristjani nosimo velik delež krivde. Ta miselnost naj bi pripomogla k bolj pokornemu in pobožnemu življenju katoličanov:

K zadnimo je letu dobru in potrebnu zamerkat; de se nimamo le na te Jude jeziti, al pak po naturi enu usmilenje čez Jezusa samu imeti; ampak sami čez nas imamo se jeziti, dokler tudi mi smo ta uržoh tega trplenja, mi se imamo sramvati, kir Jezus toku za naše izveličanje trpi, mi se pak malu ahtamo. (Stržinar 1730, 12)

Če so baročne pesmi pri vernikih želele vplivati na njihovo čustveno doživljanje Jezusovega trpljenja ob postajah križevega pota, pa so duhovniki prve polovice 19. stoletja, t. i. poznega razsvetljenstva, poudarjali nezadostnost čustev (npr. žalost, jeza, usmiljenje), ki jih verniki doživljajo ob spominu na Kristusovo trpljenje in smrt, ne da bi razumeli njegov pravi namen in pomen, kar je seveda vplivalo tudi na spremembe v slovenski nabožni pesmi:

[M]enijo, de jih bode Bog Oče, posebno lubil, če njegoviga Sinu Jezusa krvave kapelce s solznimi očmi pregledujejo; ob kratkim, ako se čez neusmilene Jude v srcu togote; z Jezusam pak srčno 
občutlivo in stanovitno usmilenje imajo. In ta je tretja, splošna in nar bolj škodliva pomota. (Dolinar 1833, 101)

V slovenski ljudski pesmi se po Kumrovi (1997) Judje iz Jezusovega časa pojavljajo v legendarnih pesmih, ${ }^{9}$ srednjeveški Judi oz. Židi pa le v dveh pripovednih pesmih. V prvi pesmi iz Frama z naslovom Sveta hostija onečaščena (Štrekelj 1895-98, št. 519), zapisani leta 1845, je omenjen neki "zamorčič" (sefard ali tudi saracen), ki je oskrunil hostijo. Druga pesem Cerkveni ropar proda Judom sv. hostijo (Štrekelj 1895-98, št. 703) je bila zapisana leta 1838 in pripoveduje o Jakcu, ki je Judom iz Gorice prodal hostije. Nastanek prve pesmi naj bi odražal dogodke, o katerih so slovenski verniki slišali med romanjem v Kompostelo, druga pesem bi lahko bila povezana s sodnim procesom v Kamniku iz leta 1643 (Kumer 1997, 91). V Štrekljevih Slovenskih narodnih pesmih (1904, št. 6437), v razdelku Pesmi pobožne, je objavljen še odlomek Majarjevega zapisa iz Gorjan v Ziljski dolini; pesem z naslovom Devojka in Jud naj bi se izvajala pri procesiji s svetim Rešnjim telesom, v njej pa je omenjen »črni Jud« (glej Slavjan 1875, 11), kar bi prav tako lahko nakazovalo sefarda. Dodajamo še pesem št. 6211 iz razdelka V peklu goreča duša, ki naj bi po Štreklju spadala k pesmi št. 703 .

V slovenski nabožni pesmi se protijudovska tematika pojavlja še posebej v eshatoloških besedilih o smrti, sodbi, peklu oz. pogubljenju in nebesih oz. zveličanju. V slovenskem rokopisnem izročilu se je tema o štirih poslednjih stvareh človeka ohranjala $v$ baročni meditativni prozi, prevedeni oz. predelani po knjigi kapucina p. Martina Cochemskega, npr. Bukve od štirih poslednjih reči (NRSS Ms 037), Smrt, sodba, peku, nebešku kralestvu (NRSS Ms 034) (Ogrin 2017), ki v času jožefinizma ni bil zaželen in so bila njegova dela podvržena državni cenzuri (Ogrin 2020, 128). Prvo slovensko rokopisno pesem o štirih poslednjih rečeh najdemo pri tuhinjskem župniku Paglovcu (ok. 1733), o tej temi pa so še posebej radi premišljevali jezuitski misijonski pridigarji, kot je bil Primož Lavrenčič (Smolik 2011, 1447).

9 V članku ni navedeno, katere pesmi so to. Po hitrem pregledu tretjega zvezka najdemo Jude iz Jezusovega časa npr. v naslednjih pesmih: Marija daruje golobca dva (št. 4975), Jezus jemlje slovo od Marije (št. 6412), Jezus brez žlahte (št. 6419), Judje zmerjajo Marijo (št. 6436), Jezus nese križ na Kalvarijo in se da križati (št. 6438), Kako pojde Jezus s križa, ko je že na pol mrtev! (št. 6444), Razdavanje pisanek (št. 6500). 
Gornjegrajski župnik Ahacij Stržinar je leta 1729 prvi objavil pesem Od poslednih reči tega človeka. Pripoveduje, da bodo na sodni dan v dolino "Josaphat" prišli tako tisti, ki so v nebesih (Abel), kot tisti v peklu (Kajn). Poudarjen je sram grešnikov, ki bodo izpostavljeni na sodni dan. Mednje spadajo ne samo nespokorjeni kristjani, temveč tudi pogani (ajdje), Turki (muslimani) in Judje. Na koncu najdemo poziv k pokori. Pesem se je prepisovala v celotnem 18. stoletju (glej Maurerjevo in Krebsovo pesmarico). Leta 1826 je Stržinarjevo pesem predelal takratni radgonski kaplan Peter Dajnko. V njej sta poudarjeni minljivost sveta in umrljivost človeka, kar je posledica greha, vendar ne zasledimo več omemb grešnikov drugih veroizpovedi.

Vsi ajdje, Turki, Judje,

Kervični kristjani

Vsi nausmileni tudi

Bodo ferdamani;

Kir sodba bo v te viži,

Niste v mojm imenu

Tem ubogim dali špiže,

Bote pogubleni. (Stržinar 1729, 59)

To tematiko so med ljudmi širili zlasti organisti, ki so pesmi vernikom prepevali sami. V pesmi kranjskega organista Jožefa Ambrožiča Oh moj človg, al češ verjeti iz leta 1775 (NUK Ms 1318, zvezek IV) izvemo, da bo grešnik po smrti poslan v pekel, Turki in Judi pa naj bi samoumevno prišli v večno pogubljenje:

Zdej vsi spoznamo leto pravico,

če grešnik še v grehah živi,

De bog na stri mo zatu krivico,

če ga lih večnu pogubi.

O kaj ferdama Turkov nu Judov,

tudi kristjanov, se boš začudov,

noter glabokejši posadi. (Anton Kadunc, fol. 055v)

Ambrožičeva pesem o peklu iz leta 1775 (NUK Ms 1318, zvezek IV) pripoveduje o Kajnu in Judi Iškarijotu, ki žalujeta v peklu. Dolgotrajnost njunega trpljenja je ponazorjena celo s konkretnimi števili: Kajn prebiva v peklu 
"čez pet tavžent lejt«, apostol Juda pa "sedemnajst stov lejt». Poudarjena je misel, da rešitev iz pekla ni mogoča. Organisti so z vrsto eksemplov obtoževali skrunjenje Marijine podobe, v zvezi s tem pa tudi Judo obtožili sovraštva do Marije:

Judež Škarjot Marijo

je sovražu vselej, zdej se žge s kampanijo,

v pekli bo vekumej, Ki so drugi exempli, na morem zreč vsega, potler bi sami rekli, o Buh nas vari tega. (Anton Kadunc, fol. 110v)

Druga skupina nabožnih pesmi, kjer je prisotna izrazita protijudovska motivika, so pasijonske pesmi, ki pripovedujejo o Jezusovi obsodbi, trpljenju in smrti na križu. V teh pesmih so Judje prikazani kot trdovratneži, neusmiljeni mučitelji in krivci za Kristusovo smrt. V Paglovčevi pesmi Od sedem žalosti Matere Božje (Črno se očem gvantat) spremljamo Kristusovo trpljenje z očmi njegove matere Marije. Prve tri žalosti se navezujejo na dogodke iz Jezusovega otroštva: obrezovanje, beg Jožefa in Marije v Egipt ter iskanje Jezusa v Jeruzalemu. Naslednje štiri žalosti so povezane $z$ velikonočnim dogajanjem od Jezusovega prijetja, križanja, smrti do pogreba. Pisec pesmi je za Jezusovo obsodbo na smrt s križanjem neposredno obtožil Jude, čeprav nam evangeliji poročajo, da je obsodbo izrekel rimski guverner Poncij Pilat (glej Lk 23,13-25).

Četrta tvoja žalost

Jezusa ven pela

Judovska trdovratnost

Križ mu na ramo da:

Ti pruti njemu tečeš

Milu jemleš slovu,

Kumaj besedo zrečeš

Taku je teb’ britku. (Paglovčeva pesmarica, fol. 153r)

Kot neusmiljene mučitelje jih je opisoval vikar ljubljanske stolnice Maksimilijan Redeskini, kar je ponovno odraz teženj slovenske 
nabožne pesmi poznega baroka vplivati na vernikovo čustveno doživljanje Jezusovega trpljenja v obliki žalosti, usmiljenja in jeze. Tudi opisi mučenja, ki naj bi ga Jezusu prizadejali Judje, niso odraz predstave, ki nam jo podajajo evangeliji, saj ti omenjajo le upraviteljeve vojake (glej Mt 27,27-31).

Kader se opašeš,

'nu prevezuješ,

Spomni na štrike,

'nu ket'ne ta čas:

Kader se čevle

na noge obujeřs,

Zmisli na pote,

k' njeh je sturil za nas:

Ke so 'ga Judje

sem ter kje suvali,

Za lase vlačili,

po zemli valali,

Suni 'ga! vdar' 'ga!

so vpili na glas. (Redeskini 1775, 166)

Juda Iškarijot je $\mathrm{v}$ pasijonskih pesmih 18. in 19. stoletja prikazan kot izdajalec in posredni krivec za Jezusovo smrt. Kot tak je prikazan tudi v evangelijih (glej Mt 26,14; Mr 14,10; Lk 22,3 in Jn 12,4).

Judaž Škarjat se perdružal

Jezusa s folš srcam kušal

Hudim Judam ga čez dal

V grozno martro ga izdal (Paglovčeva pesmarica, fol. 150r)

Judež joger tvoj nezvesti

S kušuvanjam te je iztav

Tisti k je smev per tebi jesti

Za dnarje te je prodav (Janez Škof, 073v)

V obdobju razsvetljenstva v pesmaricah ni bilo več poudarjene miselnosti, da se Judje ne morejo odrešiti in gredo po smrti samoumevno v pekel, kraj pogubljenja, temveč so slovenski duhovniki v molitvah, ki so bile dodane pesmim, prosili Boga, naj Jude milostno usmeri h krščanstvu, kjer se bomo 
združili v eni veri. V obdobju poznega razsvetljenstva oz. začetka romantike tako pri slovenskih duhovnikih še ne zasledimo sprejemanja judovske religije kot enakovredne krščanski, saj je Luka Dolinar, župnik v Šmartnem v Tuhinju, v svoji natisnjeni pesmarici še pozival k njihovi spreobrnitvi:

O Bog! Še Judam gnado daj, / De k veri se podajo; / Ti jih razsvetli, jim povej, / De Jezusa spoznajo. / Odvzemi 'z njih srca slepoto, / Lubezen jim noter zapiš', / De najdejo pravo svetlobo / Per Jezusu z nami v en' hiš'. (Dolinar 1833, 130)

V drugi polovici 19. stoletja je v okviru prenove slovenske cerkvene pesmi razvidno, da se v pasijonskih pesmih Judje več ne omenjajo, temveč najdemo med Kristusovimi mučitelji tolovaje in trinoge, tj. nasilne oblastnike:

Tolovaji Te obdali,

Te zvezali in peljali,

Uklenili Ti roke,

Ktere celi svet drže.

Jezus, daj i. t. d.

Trinogi so Te sodili,

»Križaj ga!« hudobni vpili,

Tepli, bili, da se kri

Iz bolečih ran cedi.

Jezus, daj i. t. d. (Cecilija 1883, 119)

\section{Sklep}

Uvedba lavretanskih litanij v slovenskem jeziku na začetku 17. stoletja je pripomogla, da so tam omenjene starozavezne predpodobe za Marijo prešle v številne slovenske nabožne pesmi 18. stoletja, ki so bile v ospredju naše raziskave. Med njimi so se še posebej uveljavile in med ljudstvom priljubile naslednje predpodobe: sedež modrosti, lilija, roža brez trnja, Davidov stolp in skrinja zaveze. Pri tistih pesmih, ki so še danes del cerkvenega bogoslužja (npr. Zdrava morska zvezda), lahko najbolj nazorno prikažemo, kako so se v stoletjih vsebinsko spreminjale in s tem vplivale na vernikovo doživljanje starozaveznih predpodob. Tako je v okviru prenove slovenske cerkvene pesmi že v drugi polovici 19. stoletja razvidno 
bolj pozitivno povezovanje Marije s tipom Eve, saj se je v času cecilijanskega gibanja uveljavil izraz nova Eva, kar se je obdržalo še v 20. stoletju. Slovenski pisci nabožnih pesmi so Marijo povezovali še z drugimi ženskimi starozaveznimi liki, med katerimi izstopajo Suzana, Estera, Judita in Rahela.

V slovenskih pesmaricah v obdobju baroka je razviden slabšalni odnos do Judov, ki so ga katoliškim vernikom posredovali tako predstavniki Cerkve (župniki) kot laiki (organisti). Tovrstne pesmi se osredotočajo na specifične dogodke iz Svetega pisma, kot so greh prvih staršev Adama in Eve (t. i. izvirni greh), Judovo izdajstvo Jezusa ter obsodba, trpljenje in smrt Jezusa Kristusa. Eshatološke pesmi o štirih poslednjih stvareh človeka so v pesmaricah 19. stoletja začele izzvenevati, s tem pa tudi tematika Judov, obsojenih na večni pekel. Judovska krivda je prikazana kot kolektivna, kar je še posebej nakazano v pasijonskih pesmih. Tam so Judje prevzemali kolektivno krivdo za Kristusovo smrt, njihova omemba pa v uradnih pesmaricah Katoliške cerkve v drugi polovici 19. stoletja že popolnoma izzveni. Čeprav je Katoliška cerkev šele leta 1965 podala izjavo, da odgovornosti za Jezusovo smrt ne smemo pripisovati vsem Judom, to ne pomeni, da že predtem ni obsojala antisemitizma in protijudovstva. 


\section{Rokopisni viri}

Neznani rokopisi slovenskega slovstva (NRSS):

Kadunc, Anton. Ms 108.

Škof,Janez. Rokopis iz Zaklanca, Ms 116. Narodna in univerzitetna knjižnica (NUK):

Ambrožič, Jožef. Cerkvene pesmarice, Ms 1318.

\section{Reference}

Ambrožič, Matjaž. 2011. Cerkvene razmere v Japljevem času. V: Marjeta Humar, ur. Japljev zbornik, 9-30. Kamnik; Ljubljana: Občina; Založba ZRC SAZU.

Avsenik Nabergoj, Irena. 2016. Zgodovina protijudovstva in antisemitizma $v$ Evropi. Ljubljana: Slovenska matica.

Bronner, Simon J. 2007. Introduction. V: Simon J. Bronner, ur. The Meaning of Folklore: The Analythical Essays of Alan Dundes, 382-385. Logan: Utah State University.

Brozovič, Maruša. 2019. Svetopisemske in ljudske osnove ter literarne oblike motiva Marije v slovenskem pesništvu med obema svetovnima vojnama. Doktorska disertacija. Teološka fakulteta Univerze v Ljubljani.

Cecilija. 1883; 1902. Cerkvena pesmarica. Zv. 1; zv. 2. Celovec: Družba sv. Mohorja $\mathrm{v}$ Celovcu.

Dolinar, Luka. 1833. Pesme v godove in praznike celiga leta. Ljubljana: Joshef Blasnik

Gambero, Luigi. 1999. Mary and the Fathers of the Church: The Blessed Virgin Mary in Patristic Thought. San Francisco: Ignatius Press.

Gans, Evelin, in Joep Leerssen. 2007. Jews. V: Manfred Beller in Joep Leerssen, ur. Imagology: The Cultural Construction and Literary Representation of National Characters: A Critical Survey, 202-208. Amsterdam; New York: Rodopi.
Foglarjeva pesmarica. R 281102 (II Cd 10255).

Paglovec, Franc Mihael. Cantilenae variae partim antiquae partim novae in hunc libellum transcriptae, ne pereant, et oblivioni dentur ac ut posteris devoto usui esse queant, R 0 75843/adl. 1.

Healy, Margaret I., BVM. 1985. Mary, Seat of Wisdom, Reflection of the Femininity of God. V: Carol Frances Jegen, ur. Mary According to Women, 33-50. Kansas City: Shreed \& Ward.

Jobes, Karen H. 2005. 1 Peter. Baker Exegetical Commentary on the New Testament. Michigan: Baker Academic.

Kumer, Zmaga. 1997. Židje v slovenski ljudski pesmi. Musicological Annual 33: 9195. https://doi.org/10.4312/mz.33.1.91-95

Laato, Anni. 2016. Eve, Rebecca, and Mary as prophetical images of the church. V: Take Another Scroll and Write: Studies in Interpretive Afterlifte of Prophets and Prophecy in Judaism, Christianity and Islam. Eisenbrauns: Åbo Akademi University.

Lechner, Gregor Martin. 1994. Sedes sapientiae. V: Remigius Bäumer in Leo Scheffczyk, ur. Marienlexikon 6. St. Ottilien: EOS Verlag.

Livak, Leonid. 2010. The Jewish Persona in the European Imagination: A Case of Russian Literature. Stanford: Stanford University Press.

Lukman, Franc Ksaver. 1958. Himne rimskega brevirja. Celovec: Samozaložba.

Matteoni, Francesca. 2008. The Jew, the Blood and the Body in Late Medieval and Early Modern Europe. Folklore 119: 182-200.

Mlakar, Anja. 2019. Skrivnostni tujec in demonski sovražnik. Ljubljana: Založba ZRC SAZU. 
Nitz, Genoveva. 1993. Rahel. V: Remigius Bäumer in Leo Scheffczyk, ur. Marienlexikon 5. St. Ottilien: EOS Verlag.

Obchinzka knisicza zpitavanya teh pet glavnih stukov maloga katekizmussa. 1764 . Gradec: Pritiz kena pri Witmonstetarzkih erbih.

Oblonšek, Cecilija. 2018. Liturgična glasba po drugem vatikanskem cerkvenem zboru in doprinos Gregorja Zafošnika $\mathrm{v}$ glasbeno zakladnico pokoncilske Cerkve na Slovenskem. Edinost in dia$\log 75: 139-161$.

Ogrin, Matija. 2020. Poznobaročni slovenski rokopisi - literarna tradicija v spoprijemu z razsvetljensko cenzuro. V: Luka Vidmar, ur. Cenzura na Slovenskem od protireformacije do predmarčne dobe, 119-150. Ljubljana: Založba ZRC.

- - -. 2019. Slovensko slovstveno izročilo: drobci slovenskega slovstva, izročeni v rokopisih. Celje; Ljubljana: Celjska Mohorjeva družba; Društvo Mohorjeva družba.

- - -. 2017. Slovenski rokopisi o štirih poslednjih stvareh človeka in baročno eshatološko izročilo. V: Aleksander Bjelčevič, Matija Ogrin in Urška Perenič, ur. Rokopisi slovenskega slovstva od srednjega veka do moderne, 33-41. Ljubljana: Znanstvena založba Filozofske fakultete.

Rahner, Hugo. 1964. Symbole der Kirche: Die Ekklesiologie der Väter. Salzburg: O. Müller.

Rajšp, Vincenc. 2011. Jožefinizem in jožefinske reforme na Slovenskem. V: Miha Preinfalk, ur. Neznano in pozabljeno iz 18. stoletja na Slovenskem, 75-84. Elektronska izdaja. Ljubljana: Zgodovinski inštitut Milka Kosa ZRC SAZU; Slovensko društvo za preučevanje 18. stoletja.

Redeskini, Maksimilijan. 1775. Osem, inu šestdeset sveteh pesm, katire so na prošnje, inu poželenje več brumneh duš na sivitlobo dane. Ljubljana: Aloysio Raab.
Scharbert, Josef. 1989. Eva. V: Remigius Bäumer in Leo Scheffczyk, ur. Marienlexikon 2. St. Ottilien: EOS Verlag.

Schmidt, Margot. 1993. Rose. V: Remigius Bäumer in Leo Scheffczyk, ur. Marienlexikon 5. St. Ottilien: EOS Verlag.

Schildenberger, Johannes, in Josef Scharbert. 1988. Bundeslade. V: Remigius Bäumer in Leo Scheffczyk, ur. Marienlexikon 1. St. Ottilien: EOS Verlag, 1988.

Söll, Georg. 1989. Eva-Maria-Parallele. V: Remigius Bäumer in Leo Scheffczyk, ur. Marienlexikon 1. St. Ottilien: EOS Verlag.

Slavimo Gospoda. Bogoslužna pesmarica in molitvenik. 1988. Celovec: Dušnopastirski urad.

Sebald, Eva. 1989. Eva-Maria. V: Remigius Bäumer in Leo Scheffczyk, ur. Marienlexikon 2. St. Ottilien: EOS Verlag.

Smolik, Marijan. 2011. Odmev verskih resnic in kontroverz $v$ slovenski cerkveni pesmi od začetkov do konca 18. stoletja. Inavguralna disertacija. http://ezb.ijs. si/fedora/get/ezmono:ovr/VIEW/ (pridobljeno 1. 9. 2020).

Stržinar, Ahacij. 1729. Katoliš kršanskiga vuka pejsme. V Nemshkim Gradzu: per Widmanstadianskih Erbizhah.

- - -. 1730. Pejsem od teh velikih odpustikov. Labaci: formis J.G. Mayr.

Škulj, Edo. 2003. Odloki o cerkveni glasbi. Ljubljana: Družina.

Štrekelj, Karel, ur. 1895-1898; 1904-1907. Slovenske narodne pesmi. Zv. 1; zv. 3. Ljubljana: Slovenska matica.

Toš, Marjan. 2012. Zgodovinski spomin na prekmurske Jude. Ljubljana: Založba ZRC SAZU.

Valenčič, Vlado. 1992. Židje v preteklost $i$ Ljubljane. Ljubljana: Park. 